\title{
RELASI AGAMA DAN PILIHAN NASABAH: GROUNDED THEORY DAN REPOSISI AGAMA PADA PILIHAN NASABAH BANK SYARIAH DI BENGKULU
}

\author{
Hardivizon \\ Mhd. Sholihin \\ Anrial \\ (Program Studi Perbankan Syariah, Jurusan Syariah dan Ekonomi Islam STAIN Curup. Email: \\ hardi.vizon@gmail.com, mshoy84@gmail.com, anrialma@gmail.com)
}

\begin{abstract}
This paper certainly examines the relationship between religion and consumer's choice towards the islamic bank in Bengkulu, Province. Concerning in religion preference system and its relation with consumer's choice the research is crucially expected to discover the relationship between religion, and the consumer's choice of islamic bank in Bengkulu. The reason why the issues must be studied is from theoritical foundation in which belief system like religion, and rationality is a main factor determining the consumer's choice towards islamic bank in varied-cases (Yusof; Bahari; Adanan: 2014). Hence, there are various facts as an important setting of research - moeslem population in Bengkulu; level of FDR (finance to deposits ration) for many islamic bank in Bengkulu is 182,3\% and also NPF level is 3.30\%. Based on this setting, the study intentionaly uses the grounded theory as approach. It directly legitimates two theories as guidance for the research - rationality choice theory and shopping preference theory.

The research successfully finds a set of thesis that religion's rules in consumer's choice of islamic bank can be described shortly in two models-religion as Model of" and "for Reality. These models emerge in consumer's behaviour of how they select the islamic bank in Bengkulu. Empirically, it can be attested from the perception, and definition toward islamic bank as a personal experience. In fact, Islam as a part of religions modified as justification for their choice. Whilst consumers tend to be a loyal consumer of Islamic bank based on the belief-- framework produced from their religion, for some users it is eventually because of the economics interest. For example, islamic bank choice is based on the ultimate-goal to gain exceeded-profit rather merits offered by the conventinal bank.
\end{abstract}

Kata Kunci: Religious Taste, Bank Choice Behaviour, Religion preference system, Consumer's choice, and rational choice.

\section{PENDAHULUAN}

Frank J. Lechner (2009) telah mengindentifikasi pandangan paling awal dari Adam Smith dimana Smith menyakini bahwa selain peran pemerintah, institusi lain seperti agama juga mempengaruhi perilaku ekonomi (Frank J. Lechner, 2006). Pada dasarnya, mengutip pandangan James A. Beckford, sesungguhnya struktur ekonomi dan sosial adalah produk dari interaksi antara agama dengan hampir seluruh aspek kehidupan, terutama interaksi yang terjadi pada level individu, kelompok, organisasi dan masyarakat secara umum (James A. Beckford, 2003). Agaknya dapat ditegaskan bahwa agama memiliki peranan dalam membentuk struktur sosial, bahkan menjadi hal yang determinan mempengaruhi perilaku manusia, tidak terkecuali perilaku ekonomi. 
Ada banyak aspek ekonomi yang sesungguhnya dipengaruhi oleh agama. Dari aspek-aspek produksi, distribusi, hingga konsumsi. Dalam kondisi ini Dale W. Wimberley mengilustrasikan hal tersebut dengan kalimat "menjadi religius" dimana ekonomi sesungguhnya dapat mendorong seseorang menjadi agamis, melalui perhatian yang intens terhadap moralitas dan nilai-nilai agama dalam melakukan aktivitas ekonomi (Dale W. Wimberley, 1984). Pertanyaannya adalah bagaimana sesungguhnya agama membantu, paling tidak ia menjadi fondasi dari pilihan ekonomi individu? Michael Chibnik dengan mengutip pandangan White, mengemukan satu tesis bahwa memahami bagaimana manusia memutuskan pilihan sesungguhnya tidak dapat dilakukan tanpa memperhatikan faktor-faktor yang menentukan pilihan apa yang tersedia bagi manusia, termasuk pengaruh agama (Michael Chibnik, 2011). Pandangan White ini secara implisit dapat dipahami bahwa pilihan manusia merupakan satu yang kompleks. Pilihan pada umumnya memerlukan seperangkat pertimbangan yang dapat berasal dari hal yang berada di luar diri manusia, seperti agama dan pengetahuan. Dalam konteks ini kemudian pilihan ekonomi individu bukan sesuatu yang bersipat "reflektif" dan spontan tetapi sesungguhnya keputusan untuk memilih sesuatu dihasilkan dari sesuatu yang bersipat kultural. Begitu juga pilihan konsumen terhadap satu produk. Pilihan konsumen terhadap satu produk adalah yang kompleks. Tidak hanya didasarkan pada utilitas, atau nilai guna, tetapi pilihan tersebut terkadang bersipat kultural. Pilihan individu terhadap produk merupakan satu jejaring yang memiliki hubungan kondisional antara lingkungan, nilai budaya, dan norma agama. Michael Chibnik menyebut kecenderungan tersebut sebagai "dependency choice" atau pilihan yang selalu tergantung pada "sesuatu" yang ada di luar diri manusia. Dalam konteks inilah kemudian pilihan konsumen terhadap perbankan syariah perlu dipahami. Apakah seutuhnya pilihan konsumen terhadap produk-produk yang ditawarkan oleh bank syariah didasarkan pada hal-hal yang bersipat kultural seperti agama atau bersipat rasional seperti utilitas dan keuntungan semata?

Hayat M. Awam dan Khuram Shahzad Bukhari (2011) memperlihatkan kecenderungan pilihan konsumen terhadap Bank Islam di Pakistan dimana konsumen lebih bersipat rasional dalam menentukan kriteria pilihan terhadap bank islam. Kecenderungannya, di Pakistan konsumen lebih tertarik mempertimbangkan kriteria seperti product features; kualitas pelayanan sebagai faktor yang menjadi fondasi atas pilihan. Hayat M. Awam dan Khuram Shahzad Bukhari menemukan bahwa agama tidak terlalu menjadi faktor determinan dalam pilihan konsumen terhadap bank-bank syariah di Pakistan. Sementara itu studi yang dilakukan oleh Muhamad Abduh dan Raditya Sukmana (2011) terhadap perilaku penabung pada bank syariah di Indonesia, memperlihatkan kecenderungan bahwa tingkat bunga dan income menjadi faktor yang dominan mempengaruhi perilaku konsumen untuk menabung di bank syariah. Berbeda dengan riset Awam dan Bukhari, MUI(Majelis Ulama Indonesia) cenderung melihat adanya dinamika pilihan konsumen terhadap bank syariah, untuk konteks Indonesia. MUI memahami setidaknya ada dua aspek pertimbangan bagi nasabah memilih bank syariah, yakni: Pertama, aspek 
emosional dimana nasabah mendasarkan pilihan mereka pada keyakinan; emosi yang bersipat subjektif seperti memilih bank syariah didasarkan pada keyakinan agama — jika ia beragama Islam, ia merasa harus memilih bank syariah. Kedua, aspek rasional: dimana nasabah memilih bank syariah didasarkan pada hal-hal objektif seperti pilihan terhadap bank syariah disebabkan oleh faktor ekonomi-bank syariah lebih menguntungkan ketimbang bank konvensional (Brilyan Rahmat Sukhmono, 2011). Merespon kecenderungan ini kemudian MUI berupaya mengeluarkan fatwa terkait produk yang ditawarkan oleh bank syariah dengan intens memperhatikan nalar konsumen, sehingga nasabah mendapatkan dua keuntungan ketika bertransaksi di bank syariah, dan itu adalah keuntungan di dunia (utilitas) dan akhirat (keberkahan).

Sementara itu, Dalfiza Mohd. Yusof; Zakaria Bahari; dan Ahmad Azrin Adanan (2014), melalui artikel mereka The Relationship between the Bank Choice Determinants and the Acceptance of Musharakah Mutanaqisah Home Financing among Malaysian Muslim, memperlihatkan kecenderungan adanya hubungan positif antara konsumsi terhadap produk pembiayaan musharakah mutanaqishah dengan pilihan terhadap bank di Malaysia. Penelitian ini agaknya mengindikasikan bahwa produk adalah faktor dominan yang mempengaruhi pilihan nasabah terhadap bank Islam. Riset yang dilakukan oleh Harif Amali Rivai memperlihatkan satu kecenderungan yang sedikit berbeda dengan riset terdahulu dimana masyarakat Sumatera Barat dalam memilih perbankan syariah dipengaruhi oleh faktor-faktor seperti keyakinan bahwa bunga bank bertentangan dengan agama, diikuti oleh alasan lain seperti keramahan petugas serta persepsi bahwa berurusan dengan bank syariah lebih cepat dan mudah (Harif Amali Rivai). Risetriset yang diuraikan tersebut mengandaikan bahwa ada variasi faktor-faktor yang mempengaruhi pilihan konsumen terhadap bank syariah. Lantas, bagaimana dengan konsumen di provinsi Bengkulu? Apakah ada relasi yang kuat antara agama (sebagai sistem preferensi) dengan pilihan nasabah dalam memilih bank syariah?.

Tercatat 95\% masyarakat di provinsi Bengkulu memeluk agama Islam, sementara itu 4\% sisanya beragama Kristen dan Katolik, dan $1 \%$ lainnya memeluk agama lain. Data ini menunjukkan bahwa islam adalah agama mayoritas di provinsi Bengkulu. Demikian, apakah Islam memiliki relasi dengan pilihan umat Islam terhadap bank syariah di Bengkulu? Memahami relasi ini agaknya penting dilakukan, mengingat bahwa di daerah lain adakalanya relasi antara agama dan pilihan konsumen terhadap bank syariah tidak selalu linier, dan memiliki korelasi yang signifikan dan erat. $\mathrm{Hal}$ lain yang mendorong mengapa riset ini penting dilakukan adalah fakta seperti yang dicatat dari Laporan Tahunan Statistik Perbankan Syariah (Islamic Banking Statistics) yang dipublikasikan oleh Bank Indonesia tahun 2013, memperlihat perkembangan BPRS (Bank Perkreditan Rakyat Syariah) di Provinsi Bengkulu cenderung stabil. Dengan total asset gross sebesar Rp. 818 miliar rupiah; pembiayaan (financing) Rp. 750 miliar; Dana Pihak Ketiga (depositors funds) Rp. 411 miliah, dengan persentasi FDR (finance to deposit rasion)/rasio pembiayaan terhadap pendanaan sebesar 182,33\%; sementara NPF (non performing financing)/kredit bermasalah sebesar Rp. 3,30\% 
(www.id.wikipedia.org, 2015). Data ini agaknya dapat dipahami bahwa ada trend positif (stabilitas) perkembangkan bank syariah di provinsi Bengkulu. Dengan demikian, dapat diasumsikan bahwa transaksi di perbankan syariah Bengkulu terlihat stabil jika dibandingkan daerah lain. Hal ini juga mengindikasikan bahwa pilihan terhadap bank syariah semakin positif. Jika demikian, apakah pilihan tersebut memiliki relasi dengan agama itu sendiri? Dalam konteks pertanyaan ini kemudian riset ini akan difokuskan, yakni untuk melihat dan memahami relasi antara agama dan pilihan konsumen terhadap bank syariah di Bengkulu.

\section{NEUMENA DI BALIK PILIHAN NASABAH: DARI PARADIGM RISET HINGGA GROUNDED THEORY}

Paradigma sebagai framework untuk observasi dan understanding yang menjadi penentu bagaimana cara memahami atau mengobservasi objek yang diteliti. Earl Babbie (2011), menyebut paradigma dengan frames of reference, yang mendasari teori sosial dan penyelidikan. Dalam konteks ini teori membantu untuk menjelaskan data. Sementara paradigma menyediakan metode untuk melihat sesuatu. Paradigma tidak menjelaskan apapun, tetapi ia menyediakan apa yang diistilahkan logical framework dimana teori dapat diproduksi. Kendati demikian, baik teori maupun paradigma terjalin melalui pencarian terhadap 'meaning' atau makna dalam kehidupan sosial. Dalam prakteknya, teori berfungsi melalui tiga cara dalam penelitian. Pertama, teori mencegah perilaku yang opportunistik dalam riset. Kedua, teori membantu melahirkan sense observasi serta pola-polanya.
Ketiga, teori dapat membentuk dan mengarahkan riset, dan mem-pointing temuan melalui observasi empirik.

Terre Blanche dan Durrheim (1999), menyatakan bahwa paradigma riset sistem yang memandu praktek dan pemikiran dalam mendefinisikan dimensi-dimensi penelitian. Thomas Kuhn mendefiniskan paradigma sebagai sebuah kluster integratif dari konsepkonsep substantif, variabel dan persoalan yang berhubungan secara langsung dengan metodologi, pendekatan dan alam. Dengan demikian, agaknya dapat dimengerti bahwa paradigma merupakan budaya penelitian dengan 'segopok' kepercayaan; nilai-nilai dan asumsi yang dapat digunakan oleh peneliti. Hal ini kemudian mendorong 'konflik' karena adanya diffrensiasi paradigma yang digunakan dalam penelitian sosial (Norman K. Denzin, Yvonna, 2000). Jack J. Baroudi (1989) mengutip pandangan Thomas Kuhn bahwa paradigma metodologis merupakan metode yang penting bagi sains dan merupakan hal yang substantif dalam satu desain penelitian (Wanda J. Orlikowski, 1988). Ini menegaskan bahwa sesungguhnya paradigma selain berkorelasi dengan teori, paradigma juga menentukan pola dan corak metode yang digunakan dalam satu kajian.

Tabel 1. Fondasi Metafisika Paradigma Riset (Norman K. Denzin, Yvonna , 2000)

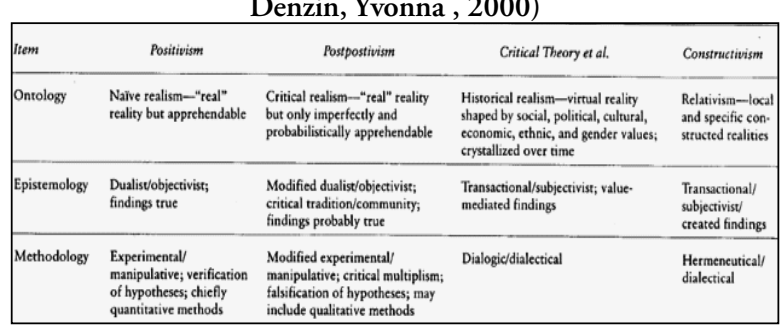

Dari tabel 3.1 di atas terlihat bahwa setiap paradigma memiliki kekhasan. Antara satu dan 
lainnya cenderung berbeda. Perbedaan tersebut terdapat pada aspek ontologis, epistemologi, dan metodologi. Dalam konteks ini, bagaimana dengan paradigma riset ini? Riset ini intens menggunakan pendekatan grounded theory: sebuah pendekatan yang dapat memahami core processes central dari perubahan. Tidak hanya itu, grounded theory sesungguhnya mampu mengidentifikasi dan mendeskripsikan fenomena, atribut, dan hakikat, serta proses psikologi-sosial. Demikian, grounded theory dikategorikan ke dalam paradigma seperti apa? Pendekatan grounded theory seringkali digunakan dalam penelitian kualitatif, terutama etnografi. Sehingga tidak berlebihan jika generasi kedua yang menggunakan pendekatan grounded theory cenderung 'menyandingkan' pendekatan ini dengan paradigma interaksionalsimbolik. Mengapa demikian?. Dengan menyandingkannya dengan paradigma interaksisimbolik, pendekatan grounded theory tidak hanya mampu mendokumentasikan perubahan dalam kelompok sosial, tetapi dapat juga memahami hakikat perubahan sosial. Pendekatan grounded theory mampu membantu peneliti melakukan sintesis data, membangun konsep dan memidrange teori yang berhubungan secara langsung dengan data. Tidak berlebihan jika kemudian dipandang dan diyakini bahwa pendekatan grounded theory merupakan alat yang ampuh dan handal diaplikasikan dalam ilmu sosial. Mengapa demikian, dan dinilai handal? Kekuatan dari pendekatan grounded theory justeru terletak pada perlakuannya terhadap data. Pendekatan ini memperlakukan data sebagai sesuatu yang orisinil dimana pendekatan ini menekankan pada the way of thinking about data, bukan menjadikan data sebagai hal yang dapat distandarkan. Ini menegaskan bahwa hubungan yang dibangun antara peneliti dan objek material, bersipat natural dan bahkan tidak berjarak. Sehingga tidak ada tujuan untuk mengontrol dan memperlakukan data sebagai sesuatu yang tidak alami, dan dapat dikontrol berdasarkan kebenaran-subjektif penyelidik. Ini kemudian yang menyebabkan pendekatan grounded theory hanya digunakan dalam penelitian kualitatif, dan agak bertentangan dengan kuantitatif yang basis paradigmanya positivistic (Janice M. Morse, 2009). Lantas apa konsekuensi pendekatan grounded theory terhadap metode serta desain penelitian ini?

Anselm Strauss dan Juliet Corbin (2009) memahami bahwa grounded theory sebagai aktivitas pengembangan teori dan praktik penelitian sosial sebagai suatu proses yang padu. Dikatakan 'padu', karena pendekatan grounded theory dikembangkan langsung dari data atau, apabila telah bersesuaian dengan wilayah penelitian, teori (grounded) tersebut dapat diolah atau dikembangkan sesuai dengan data-data yang diperoleh sesudahnya. Sekilas ada persamaan antara pendekatan grounded theory dengan pendekatan kualitatif lainnya, terutama dari sumber dan instrumen mengumpulkan data. Pendekatan grounded theory ini juga menggunakan wawancara, observasi lapangan serta berbagai jenis dokumen seperti buku harian, surat, autobiografi, peristiwa sejarah, koran dan mediamedia lain. Perbedaan mendasarnya justeru terletak pada pengembangan teori. Bagaimana hal tersebut dijelaskan?. Anselm Strauss dan Juliet Corbin menuturkan bahwa melalui pendekatan grounded theory, para peneliti bisa mencapai tujuan teoritis apa saja ketika menggunakan pendekatan tersebut. Dan sebagian besar pendekatan ini 
diarahkan untuk pengembangan teori substantif: sebuah tujuan untuk mengenali subtansi teori. Dengan demikian, pendekatan grounded theory mampu menghasilkan teori yang 'padat', baik secara konseptual maupun variatif, dimana teori berkonsep padat dimaknai sebagai teori yang kaya akan pengembangan dan hubungan konsep-hal ini, tulis Anselm, tentu berhubungan dengan kedalaman yang dicapai ketika menelaah data dan diperiksa secara sistematis dengan menggunakan data-data tersebut. Tujuan yang didesain demikian rupa, menyebabkan pendekatan grounded theory memiliki prosedur yang relatif unik dan berbeda tatkala dibandingkan dengan pendekatan lainnya.

Perbedaan mendasar dalam aspek prosedur, pendekatan grounded theory memiliki beberapa prosedur yang membuatnya jadi efektif dan akhirnya diyakini berpengaruh. Prosedurprosedur tersebut adalah 'perbandingan konstan"; pengajuan pertanyaan yang bersipat generatif dan berhubungan dengan konsep secara sistematis, sampling teoritis, prosedur pengkodean secara sistematis, kerangka penelitian untuk 'memadatkan' konsep, dan variasi dan integrasi konseptual. Prosedur lainnya adalah konseptualisasi dan pembuatan diagram 'matriks kondisional'. Matrik kondisional tersebut dapat diilustrasikan sebagai serangkaian lingkaran, atau satu lingkaran berada dalam lingkaran lainnya dan sebaliknya, setiap tingkat matriks tersebut berkorespondensi dengan berbagai aspek yang ada di dunia. Lingkaran terluar terdiri atas pernak-pernik kondisional yang paling 'berjarak' dengan aksi/interaksi; sebaliknya, lingkaran terdalam terdiri atas pernak-pernik kondisional yang paling dekat dengan aksi atau interaksi. Prosedur sebagaimana yang telah diurai semangkin mengukuhkan bahwa pendekatan grounded theory telah menekankan pada penafsiran secara komprehensif dan radikal- "biarkan informan yang berbicara dan simak baik-baik." Penekanan seperti itu kemudian yang memposisikan grounded theory sebagai pendekatan yang mengedepakan orisinalitas dan hubungan yang alami antara peneliti dan informan. Dalam hubungannya dengan kajian ini, data seperti apa yang dibutuhkan peneliti?. Ditegaskan sebelumnya oleh Anselm Strauss bahwa prosedur pengumpulan data antara pendekatan grounded theory dengan model deskriptif versi Geertz, tidaklah terlalu berbeda. Adakalanya melalui wawancara; observasi; dan bahkan studi kepustakaan. Tetapi tentu saja tidak semuanya diterapkan secara simultan dalam satu kajian. Pilihannya sangat tergantung pada isu penelitian, tentunya. Pilihan instrumen tersebut sangat tergantung pada jenis data apa yang ingin diproduksi dan didapatkan. Layaknya penelitian sosial lainnya, kajian ini juga mengkategorikan tiga jenis data yang akan dikumpulkan. Pertama, data primer, yakni data yang dihasilkan sepenuhnya melalui indepth-interview. Adapun bentuk-bentuk data yang dihasilkan melalui indept-interview meliputi beberapa hal, yakni: rasionalisasi pilihan terhadap bank syariah, pengalaman personal (personal-experience) sebagai nasabah bank syariah, preferensi baik agama atupun ekonomi sebagai fondasi pilihan. Wawancara dalam tipe tersebut (baca: indepth-interview) sejalan dengan karakter pendekatan grounded theory dimana lebih terfokus pada pengkodean atau kategorisasi data.

Kedua, data sekunder. Data ini dihasilkan dari studi kepustakaan dimana literatur-literatur yang berhubungan dalam aspek isu dan teoritis dikumpulkan kemudian dipilih serta dikategorisasi 
sesuai dengan kode yang dihasilkan dari data. Ketiga, data tersier. Data ini pada hakikatnya hanya menjadi pendukung untuk memahami dua data sebelumnya (baca: primer dan sekunder). Datadata ini bersumber dari berbagai buku, kamus yang dapat menjelaskan berbagai persoalan teknik seperti istilah teoritis yang muncul kepermukaan. Tentu saja 3 (tiga) jenis data tersebut belum sepenuhnya dianggap memadai, maka diperlukan jenis data lainnya yang dihasilkan dengan teknik yang berbeda. Data yang dimaksud adalah datadata yang didapatkan melalui kuesioner. Mengapa kuesioner diperlukan dalam pengumpulan data? Dalam perkembangannya, pendekatan grounded theory tidak terlalu menekankan pada teknik pengumpulan data atau data gathering techniques. Namun hal tersebut bukan bermakna bahwa pendekatan grounded theory tidak menerapkan sama sekali teknik pengumpulan data. Perbedaan yang mendasar adanya pra-syarat bahwa data dikumpulkan dalam situasi yang alamiah dan natural. Itu kemudian mensyaratkan adanya 'partisipasi' tanpa paksaan dari informan untuk memberikan data dan informasi penting. Pra-syarat itupun diberlakukan dalam teknik penyebaran kuesioner. Lantas data seperti apa yang dihasilkan melalui kuesioner dalam penelitian ini?

Meminjam pandangan Earl Babbie (2011) bahwa kuesioner digunakan dalam hubungannya dengan berbagai observasi dalam penelitian sosial. Pada umumnya kuesioner digunakan dalam penelitian survei, tetapi hal itu tidak lantas menafikan kemampuan kuesioner sebagai instrumen yang digunakan dalam penelitian eksperimen, field research, dan aktivitas pengumpulan data lainnya. Ini menegaskan bahwa kuesioner dapat diartikan sebagai alat atau instrumen yang dapat membantu melakukan observasi terhadap gejala sosial, mental, atau persepsi yang bersipat psikologis. Dalam kaitannya dengan kajian yang akan dilakukan, kuesioner ditujukan untuk memetakan opini dan kognisi nasabah terhadap bank syariah. Memotret permukaan bagaimana harapan serta opini nasabah terhadap bank syariah di Bengkulu. Datadata yang didapatkan melalui kuesioner ini, akan ditampilkan secara deskriptif. Lantas bagaimana sesungguhnya posisi data yang didapatkan melalui kuesioner ini? Pada hakikatnya, data-data yang diproduksi melalui angket ini hanya diartikan sebagai data pendukung terhadap data primer. Sehingga tidak hanya pengalaman personal dalam kaitannya dengan sistem preferensi agama, yang dapat dijelaskan, tetapi "harapan" atau personal expectation terhadap bank syariah juga dapat dipotret secara 'gamblang' dari permukaan. Dengan demikian, maka data-data kualitatif yang didapatkan melalui wawancara dan studi pustaka, kemudian diperkuat dengan data-data yang dihasilkan melalui kuesioner. Lantas, apa yang dihasilkan peneliti melalui mekanisme tersebut?.

\section{AGAMA SEBAGAI "MODEL OF" DAN "FOR REALITY: MEKANISME AGAMA MEMANDU PERILAKU DAN PILIHAN NASABAH}

Bassam Tibi (2001) memperkenalkan dua konsep penting terkait upaya memahami agama dan hubungannya dengan perilaku manusia, yakni: religion as a source of meaning, dan as incorporated into reality. Bagaimana dua konsep penting tersebut dipahami? Lantas, apa benang merah antara teori Bassam Tibi dengan temuan penelitian ini? Memahami bagaimana mekanisme agama mempengaruhi paling tidak memandu 
perilaku manusia, maka penting mengurai fungsi agama dalam struktur sosial, dan tatanan perilaku manusia. Ada dua mashab yang berbeda dalam memahami hubungan agama dan realitasperilaku dan pilihan manusia. Pertama, kelompok yang melihat adanya konflik antara kepercayaan dan realitas. Pandangan ini berangkat dari dua dikotomi, yakni agama sebagai model of reality dan agama sebagai model for reality. Agama sebagai model for reality merupakan sesuatu yang abstrak. Ia lebih terlihat sebagai world view, dogma, doktrin tentang realitas yang terkadang hadir sebagai hal yang tidak congruence, atau sebangun. Agama dalam bentuk menjadi fondasi atau setidaknya ia menjadi panduan bagi manusia untuk mendesain realitas, agar lebih baik dan sejalan dengan nilainilai universal. Agama dalam bentuk ini lebih terkesan sebagai sesuatu yang normatif. Jika sudah demikian, maka agama tidak lagi menjadi wilayah yang dapat dieksperimen melainkan ia lebih tepat didekati dengan model interpretatif. Geertz melalui interpretatif-antropologi telah menyimpulkan bahwa agama dalam bentuk normatif merupakan sesuatu yang bersipat kultural. Ia akan lebih terlihat sebagai sesuatu yang simbolik dan sistemik.

Dalam perspektif agama, konsepsi manusia tentang realitas didasarkan sepenuhnya pada pengetahuan, tetapi didirikan atas dasar kepercayaan atau belief yang bersumber dari otoritas trasendental-ketuhanan. Bentuk konsepsi tersebut tentu berbeda antara satu agama dengan agama lainnya. Misalnya, dalam agama monoteistik otoritas itu adalah Tuhan yang disebut Allah, dan segala hal yang bersumber dari-Nya. Berbeda dengan agama primitif, yang memahami otoritas dalam bentuk spirit dan magis. Konsepsi-konsepsi itu kemudian yang menentukan struktur sosial, perilaku bahkan interaksi yang diekspresikan oleh pemeluk agama. Berbeda dengan kemudian dengan agama sebagai model of reality; ia berhubungan secara langsung dengan representasi dari objek. Lebih konkrit, dan ditampilkan secara selaras dengan objek-dogma, dan norma-norma. Sederhananya, agama sebagai model of reality meruapakan kepercayaan yang diekspresi didasarkan pada ruang, waktu dan kultur dimana agama diterima sebagai konsepsi. Agama dalam model ini kemudian yang menjadi field atau lapangan studi antropolog, sosiolog dan ilmuwan sosial lainnya.

Adalah Maurice Merleau-Ponty, seorang intelektual prancis, yang telah menghabiskan usianya meneliti tentang kesadaran manusia sebagai wujud dari pengalaman. Ia pula kemudian yang mengembangkan fenomenologi dan menggunakannya dalam kajian terhadap agama. Kesadaran bagi Maurice Merleu-Ponty menjadi pusat dari semua tindakan dan perilaku manusia, termasuk dalam hubungannya dengan agama. Marleau-Ponty mengistilahkan agama sebagai experienced-physically (Timothy K. Beal, \& William E. Deal, 2004). Dapat dimaklumi jika Marleau-Ponty mengistilahkan agama sebagai pengalaman-fisik. Karena agama bagi manusia, dalam keseharian mereka, tidak hanya dijadikan sebagai panduan tetapi menjadi fondasi dari kesadaran. Ia tidak saja mewarnai tetapi membentuk pola, dan struktur perilaku manusia. Carl Olson (2011) melalui bukunya Religious Studies, telah menegaskan bahwa persoalan agama merupakan sesuatu yang kompleks. Kesimpulan tersebut dapat diterima, karena Carl Olson berangkat dari kesimpulan 
Robert Ellwood ketika ia mengunjungi Jepang untuk mempelajari agama di sana. Akhirnya ia menyimpulkan bahwa Jepang tidak memiliki agama. Kesimpulan ini sesungguhnya sangat tergantung pada pendekatan serta aspek yang dikaji. Barangkali yang dikaji oleh Ellwood adalah ekspresi masyarakat Jepang. Ia menemukan tidak ada relasi agama yang ditemukan dalam ekspresi keseharian masyarakat Jepang. Umumnya ekspresi yang muncul kepermukaan adalah sesuatu yang rasional dan bersumber dari dimensi ekonomi, ketimbang agama.

Penjelasan lain tentang agama muncul dari kalangan antropolog. Don Seeman (2007) melalui artikelnya Ritual Practice and Its Discontents, telah memaparkan hakikat praktek, ritual agama. Ia mengasumsikan bahwa ritual dan praktek keagamaan merupakan ekspresi dari keshalehan seseorang. Tesis ini kemudian yang menjadi pijakan awal bagi antropolog untuk mengkaji ekspresi agama di pelbagai suku, negara atau komunitas agama. Clifford Geertz (1073) misalnya, melalui kajiannya yang bertajuk The Interpretation of Culture, ia telah sukses mengkaji agama sebagai sebuah sistem kultural. Proyek Geertz ini pula yang kembali memunculkan ke permukaan pendekatan antropologi untuk mengkaji agama. Dalam pengamatan Geertz setidaknya ada 2 (dua) karakteristik proyek antropologis dalam mengkaji agama. Pertama, pendekatan yang tidak menghasilkan teoriteori utama. Pendekatan yang hanya sekadar memaparkan fakta-fakta empiris an sich. Kedua, pendekatan yang mampu membangkitkan tradisi intelektual yang kuat seperti yang dilakukan oleh Durkheim, Weber, Freud, ataupun Malinowski. Geertz lebih cenderung mengadopsi pendekatan kedua. Ia dengan teliti dan serius mengkaji agama melalui tradisi intelektual yang kuat, sehingga mampu menyimpulkan bahwa agama, tidak lain, adalah sistem kultural yang unik. Agama sebagai sistem kultural diartikan sebagai aktivitas simbolik-keagamaan yang diekspresikan dalam keseharian. Ilustrasi dan kemudian menjadi fakta yang tidak dapat dibantah ditemukan dalam perilaku umat beragama dalam mengekspresikan keyakinan atau belief terkait kehidupan seharihari, misalnya di kalangan perempuan Muslim menutup aurat yang sesungguhnya bersumber dari doktrin agama. Ia tidak hanya menjadi perilaku-keagamaan tetapi kemudian menjadi identitas yang merupakan bagian dari tradisi. Tidak hanya dalam laku sehari-hari, ekspresi agama juga ditemukan dalam aktivitas yang lebih vital dalam kehidupan manusia seperti ekonomi; politik; bahkan perilaku sosial lainnya. Bagaimana hal ini dimaknai? Kembali meminjam analisis Bassam Tibi bahwa relasi agama (baca: Islam) dan perilaku individu dapat ditemukan secara massif pada komunitas Muslim. Meskipun tidak bersipat homogen. Tetapi ada kecenderungan bahwa Islam diekspresikan dalam "laku seharihari”. Bassam Tibi menyebutkan bahwa hal itu dapat dijelaskan secara teologis dan sosiologis dimana umat Islam percaya di luar sana hanya ada satu kebenaran absolut, dan itu berlaku sepanjang zaman, dan itu adalah Al-Qur'an yang kemudian menjadi panduan utama umat Islam dimanapun. Keyakinan semacam itu kemudian yang menjadi fondasi dari perilaku umat Islam. Tidak berlebihan jika sebagian sosiolog, bahkan juga antropolog mengasumsikan agama sebaagi sistem kultural dimana agama adalah kekuatan yang paling efektif menentukan perilaku manusia.

Relasi Agama dan Pilihan Nasabah... || 9 
Ia tidak hanya berisi separangkat doktrin tetapi juga mengandungkan nilai-nilai ideologis yang mengikat para pemeluknya. Tesis semacam itu kemudian yang mendorong Clifford Geertz memeriksa agama dan hubungannya dengan sistem kultural masyarakat melalui ekspresi; ritual dan kesadaran di balik perilaku-beragama satu komunitas, misalnya etnis Jawa. Ini semangkin menegaskan bahwa ide-ide agama yang tertuang sebagai doktrin berkorelasi dengan realitas. Kendati demikian adakalanya dua hal itu (baca: agama dan realitas) justeru tidak berhubungan dan saling berjarak. Geertz telah membuktikan tesis Bassam Tibi tersebut. Ia menemukan pada suku bangsa tertentu, agama tidak menjadi fondasi dari perilaku masyarakat. Namun khusus di kalangan masyarakat Muslim, Geertz menyimpulkan bahwa dimensi simbolik dari perilaku sosial umat Islam cenderung mengartikulasikan apa yang disebut dengan religio-cultural manner. Persoalannya, apakah hal itu konsisten diekspresikan oleh umat Islam dalam berbagai dimensi kehidupan seperti dalam aktivitas ekonomi, khusus dalam perilaku konsumsi dan pilihan terhadap bank misalnya?.

Bassam Tibi (2001), menegaskan bahwa agama sebagai model of reality terdiri dari simbolsimbol yang berhubungan secara langsung pada objek-ril. Ia lebih tampak sebagai ekspresi dari sesuatu yang lebih trasendental dan bersumber dari otoritas ketuhanan seperti kitab suci dan lain sebagainya. Sementara, agama sebagai model for reality berisikan konsep-konsep dan doktrindoktrin utama bagi realitas. Ia bukan sebuah model bagi realitas, tetapi bukan model realitas itu sendiri. Dalam artian bahwa agama menyediakan seperangkat dogma, doktrin, etika, dan sistem bagi perilaku manusia dalam mendesain realitas.
Kendati demikian agama bukanlah realitas itu sendiri. Mengapa tesis itu diperkenalkan oleh Bassam Tibi?. Bassam Tibi menyakini bahwa agama mampu membentuk; mewarnai realitas. Tetapi adakalanya agama tidak secara universal dijadikan sebagai pertimbangan dalam perilaku atau "laku keseharian" manusia. Ada proses yang kemudian diistilah dengan 'sekularisasi' dalam laku keseharian manusia, dimana umat beragama tidak mempertimbangkan secara utuh dogma, dan ajaran agama bagi perilaku keseharian. Dalam konteks ini kemudian tesis, "..religion is a model for reality and not a model of it." Meskipun demikian, ada hubungan gradual antara agama dan realitas, hal tersebut tentu tidak mengecilkan arti hubungan antara agama dan perilaku manusia. Pertanyaannya, bagaimana dan dalam bentuk apa sesungguhnya agama memandu perilaku atau laku-keseharian manusia? Mensyarah hal ini, agaknya perlu mendalami kajian Bassam Tibi terhadap fungsi agama serta peran yang 'dimainkan' oleh agama, hingga pada akhirnya mewarnai realitas. Setidaknya ada beberapa komponen yang tidak bisa lepas dari agama. Pertama, agama sebagai sistem sosial: dimana agama menyediakan seperangkat institusi; pranata yang menentukan struktur sosial. Kedua, agama sebagai sistem kepercayaan: dalam konteks ini agama menyediakan seperangkat doktrin, dan simbol yang idealnya diekspresikan oleh pemeluk agama tersebut. Misalnya, religious symbols di kalangan umat Islam ditemukan pada konsepsi masyarakat tentang persatuan yang diikonisasi melalui sebutan umma. Secara empiris, simbolsimbol tersebut diekspresikan dalam bentuk yang relatif berbeda sesuai dengan locus, konteks 
kultural $^{1}$ dimana masyarakat Muslim hidup. Tesis itu dapat dibuktikan secara empiris, dan juga telah ditunjukkan oleh pelbagai kajian, mulai dari Clifford Geertz hingga riset yang dilakukan oleh ilmuwan sosial kotemporer seperti Bassam Tibi, misalnya. Lantas, bagaimana paparan teoritis ini dihubungkan dengan fakta yang ditemukan melalui kajian terhadap preferensi nasabah bank syariah di Bengkulu? Bagaimana sesungguhnya agama memandu pilihan mereka terhadap bank syariah?

Diagram 1.

Relasi Institusi Agama dengan Pilihan (Rokhimin, 2015)

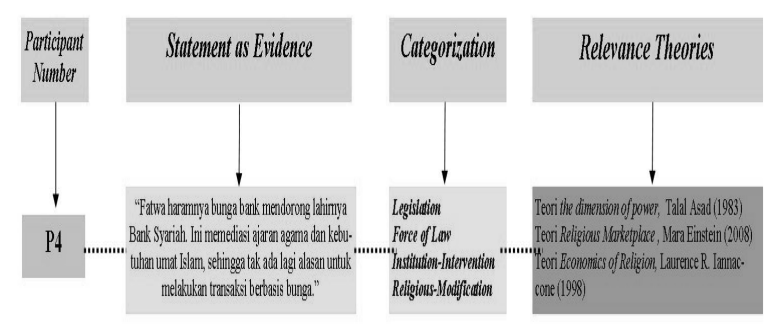

Adanya statemen yang kemudian dinilai sebagai fakta bahwa "..fatwa MUI terkait haramnya bunga bank, akhirnya mendorong lahirnya Bank Syariah di Indonesia. Ini kemudian memediasi antara ajaran agama dengan kebutuhan umat Islam, sehingga tak ada lagi alasan untuk melakukan transaksi dengan bank yang berbasis bunga" (Rokhimin, 2015). Bagaimana statemen dari partisipan ini dimaknai? Secara implisit agaknya statemen ini memunculkan 4 (empat) kategori yang akhirnya dapat menjelaskan bagaimana sesungguhnya agama memandu untuk menyebutnya membentuk pilihan nasabah bank syariah di provinsi Bengkulu. Kategori

1. Kecenderungan semacam itu kemudian melahirkan dua istilah yakni Islam Arab dan Islam lokal, dimana Islam Arab diartikan sebagai Islam yang paling orisinil sesuai dengan representasi Islam di tempat asal dimana ia diturunkan, yakni Arab. Sementara Islam lokal merupakan Islam yang diekspresikan secara integratif-interpretatif dan terpisah serta berjarak dengan Islam orisinal yang direpresentasi di Arab. tersebut adalah: legislasi; tekanan hukum; intervensi institusi (baca: ulama); dan modifikasi agama. Demikian, kategori tersebut dapat dirasionalisasikan bahwa hadirnya Majelis Ulama Indonesia melalui fatwa haramnya bunga bank dapat ditafsirkan ke dalam beberapa kategori: Pertama, fatwa tersebut merupakan upaya melakukan legislasi atas haramnya bunga bank; Kedua, fatwa tersebut diartifikan sebagai tekanan lewat hukum (force of law) agar umat Islam meninggalkan transaksi bank yang berbasis pada bunga; Ketiga, menguatnya peran MUI melalui fatwa Dewan Syariah Nasional agaknya dapat diartikan sebagai salah satu bentuk intervensi institusi agama mendukung, dan meningkatkan sphere-market bank syariah di Indonesia; dan Keempat, terlibatnya MUI dalam industri keuangan menjadi indikator tengah terjadinya modifikasi agama.

Menjelaskan fakta demikian atau evidence di atas setidaknya Talal Asad (1983) melalui artikelnya Anthropological Conception of Religion: Reflection on Geertz, telah menegaskan bahwa agama melalui institusi sosial yang dimilikinya seperti halnya Majelis Ulama Indonesia dapat menginstitusionalisasi ideologi, sehingga menentukan pola serta laku pemeluknya. Lantas, apa hubungan proses ini dengan kekuasaan atau dimensi kekuasaan agama? Talal Asad berusaha menemukan hubungan antara kekuasaan dan agama melalui sejarah perkembangan Kristen di Barat. Dari kajiannya tersebut ditemukan benang merah antara agama dan kekuasaan, dimana St. Augustine mengembangkan satu pandangan dalam agama kristen bahwa beragama secara kreatif akan memunculkan kekuasaan, atau daya yang khas dari agama itu sendiri. Tidak hanya 
itu, intervensi lembaga keagamaan menjadi faktor kesuksesan realisasi kebenaran, dan penegakan disiplin beragama. Dalam konteks ini kemudian intervensi Majelis Ulama Indonesia melalui produksi fatwa tentang Bank Syariah layak dipahami.

Demikian, fatwa tentang haramnya bunga bank yang dikeluarkan oleh Majelis Ulama Indonesia dapat dimaknai sebagai intervensi institusi agama Islam ke dalam aktivitas ekonomi. Hal ini juga pernah ditegaskan oleh partisipan, "P4", ia mengutarakan bahwa: “..Islam dengan tegas menghalalkan jual beli, tetapi mengharamkan riba. Ini perlu adanya institusi agar umat dapat mengekspresikan doktrin tersebut. Dalam konteks itu kemudian Bank Syariah didirikan, dan Bank Muamalah adalah Bank Syariah yang pertama di Indonesia. Jika institusi sudah tersedia, maka tidak ada lagi alasan bagi umat untuk bertransaksi dengan bank yang menganut sistem bunga” (Rokhimin, 2015). Doktrin larangan riba bagi umat Islam termasuk masalah pokok atau umdãh masāil yang sering dibahas, bahkan dari doktrin tersebut telah muncul berbagai teori fiqh yang kemudian menjadi fondasi dari produk-produk bank syariah. Tidak berlebihan jika kemudian persoalan riba menarik berbagai tanggapan atau ijtihad para ulama, termasuk Majelis Ulama Indonesia dengan cara mengeluarkan fatwa haramnya bunga bank. Terkait hal ini, partisipan, "P4", mengutarakan bahwa:

\section{“...fatwa MUI tentang haramnya bunga bank tujuannya adalah untuk memperkuat doktrin pelarangan riba. Penguatan itu hanya bisa dilakukan melalui institusi" (Rokhimin, 2015).}

Secara empiris, hubungan antara Majelis Ulama Indonesia dan industri perbankan syariah termanifestasi dalam satu dewan yang berada langsung di bawah organisasi Majelis Ulama Indonesia, yakni Dewan Syariah Nasional atau DSN. Dewan ini dibentuk untuk memberikan legilasi atas produk-produk perbankan syariah (Rokhimin, 2015). Ini memperkukuh satu tesis bahwa hubungan antara Majelis Ulama Indonesia merupakan hubungan kultural-politis, dimana Dewan Syariah Nasional merespon keinginan industri bank syariah untuk mendapatkan legitimasi dari otoritas agama terhadap produkproduk yang ditawarkan oleh industri bank syariah di Indonesia. Dengan proses seperti ini, produk yang ditawarkan oleh bank syariah khususnya di Indonesia dapat dipahami sebagai sesuatu yang islami dan legal dalam ajaran Islam. Diharapkan kemudian ia dapat diterima oleh kalangan umat Islam. Lantas, apakah alternatif penjelasan lain untuk mengurai persoalan ini?

Mara Einstein (2008) mengemukan satu fakta yang menarik dan relevan untuk menjelaskan mengapa kemudian bank syariah muncul, kemudian diikuti oleh campur tangan institusi seperti MUI dalam mendukung dan meningkatkan pangsa pasar bank syariah. Di Amerika Serikat, tulis Mara Einstein, 40-45\% masyarakat Amerika Serikat memberikan perhatian pada produkproduk yang berkorelasi dengan agama. Ini mengisyaratkan adanya kesadaran baru yang mulai tumbuh secara global. Kesadaran tersebut disebut dengan meningkatnya spritualitas masyarakat global, terhadap peran agama dalam realitas kekinian. Tercatat 33\% orang di Inggris Raya, 27\% di Italia, 21\% di Jerman dan 11\% di Prancis mengakui bahwa agama penting bagi mereka untuk memutuskan sesuatu dalam sektor ekonomi, politik dan sosial. Tidak berlebihan jika kemudian 
kecenderungan seperti ini mendorong industri mendesain produk yang memuat emosi dan label agama, seperti halnya Bank Syariah. Menguatnya peran agama dalam kehidupan manusia dewasa ini dapat diartikan sebagai menurunnya sekularisasi dan meningkatkan transendensi agama. Kondisi ini sesungguhnya sudah sejalan dengan fitrah manusia untuk beragama, dan menjadikan agama sebagai panduan, tidak hanya Islam tetapi hal tersebut ditemukan dalam ajaran Kristen. Sebagaimana yang ditegaskan oleh seorang partisipan "P3" berikut:

\begin{abstract}
“..manusia jika ia berlaku baik dan tulus dalam mengembangkan serta meningkatkan perekonomian, ia sudah layak dinilai sebagai pejuang penegak kerajaan Tuhan. Berarti ia telah mendasarkan aktivitas ekonominya pada nilai-nilai kerajaan Tuhan" (Panca, 2015).
\end{abstract}

Statemen partisipan di atas semangkin menegaskan bahwa setiap manusia, entah dari agama apapun memiliki sensitifitas terhadap agama. Secara teologis, setiap agama memiliki doktrin bagi umatnya agar melakoni kehidupan sehari-hari didasarkan pada doktrin agama. Hanya saja kesadaran akan agama itu tergerus disebabkan oleh dominannya nalar yang pragmatis, dan berorientasi untung-rugi. Bahkan seorang partisipan, "P1", mengutarakan bahwa dalam agama Buddha juga mengajarkan doktrin pengorbanan, dimana seorang penganut ajaran Buddha sejati mesti mendasarkan perilakunya pada ajaran tersebut. Sehingga perilaku yang diperlihatkan tidaklah 'elok' merugikan orang lain, apalagi sampai melukai orang lain, termasuk dalam aktivitas ekonomi (Slamet, 2015). Berpijak dari statemen tersebut, agaknya tidaklah mengherankan jika belakangan ini ada kecenderungan bangkitnya spritualitas baru dalam ekonomi. Mara Einstein (2008), menyebut hal itu dengan munculnya "religious marketplace": sebuah kondisi dimana agama berperan secara implisit ataupun eksplisit dalam perekonomian, atau religion operating in an unregulated market open to a variety of producers; and rational choice theory. Dalam kondisi, manusia akan memilih agama didasarkan pada kebutuhan dan tujuan yang ingin dicapai. Kemudian Finke dan Iannaccone menteorikan hal itu dengan supply-side explanation for religious change. Di dunia modern dimana intensi ekonomi telah terinstitusionalisasi dengan kuat, dan bahkan telah menjadi identitas, agama terkadang dimodifikasi sesuai dengan kebutuhannya dalam mencapai keinginan dan tujuan utama. Meskipun hal itu tidak dapat ditangkap secara mudah, tetapi meskipun abstrak, indikator dari kenyataan itu dapat dipahami. Dalam konteks ini kemudian adanya peran agama memandu pilihan nasabah layak ditafsirkan.

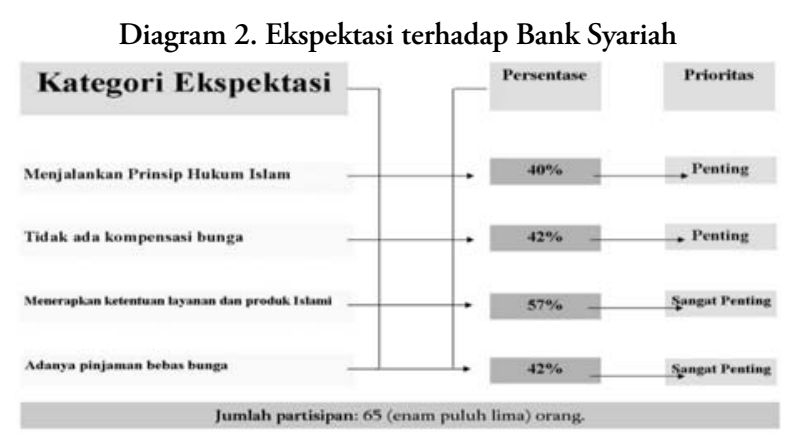

Data diatas menginformasikan tumbuhnya kesadaran atau consciousness di kalangan nasabah bank syariah di Provinsi Bengkulu, dengan memilih menjadi nasabah bank syariah setidaknya ada harapan yang bisa ditumpangkan kepada bank syariah agar selalu mengedepankan nilai-nilai syariah. Hal itu mesti terlihat secara nyata, dan jelas dalam produk dan layanan yang ditawarkan oleh bank syariah. Ekspektasi yang dipertaruhkan

Relasi Agama dan Pilihan Nasabah... | 13 
oleh nasabah bagi bank syariah tentu saja dapat dinilai sebagai modalitas penting, dan itu tidak akan diperoleh pada bank konvensional. Kesadaran akan nilai-nilai agama, yang kemudian diistilahkan akan religious awareness menjadi penentu tingkat akseptabilitas produk bank syariah di Indonesia. Mara Einstein menyebut kondisi seperti itu dengan membaiknya "pasar religiusitas" atau market for religion melalui munculnya industri keuangan berbasis pada nilainilai agama seperti bank syariah misalnya.

Mara Einstein pernah menulis bahwa:

“..where many faiths function within a religious economy, a high degree of specialization as well as competition occurs. From this it follows that many independent religious bodies will together be able to attract a much larger proportion of a population than can be the case when only one or very few fi rms have free access."

Sentimen positif terhadap agama-agama dalam aktivitas ekonomi hanya mungkin muncul jika agama hadir bukan sebagai sesuatu yang koersif, dan hegemoni. Industri-industri yang muncul sebagai wujud dari doktrin agama mesti bersaing dengan industri konvensional yang telah lama hadir sebagai produk dari kepentingan ekonomi an sich. Mara Einstein menegaskan bahwa agama berkembang seiring perannya yang kuat dalam aktivitas ekonomi, hanya bisa dan mungkin terjadi selama agama dipahami sebagai produk, bukan sebagai mandat sosial. Hal itu diartikan bahwa agama yang diejawatahkan dalam industri adalah produk dari kreatifitas manusia dalam memahami dan mengembangkan doktrin agama yang sangat abstrak. Ia bukanlah sebuah tuntutan sosial yang ideologis. Menurut Mara Einstein, dalam kondisi seperti ini kemudian agama mampu memandu pilihan manusia melalui kreatifitas manusia memahami doktrin agama.
Finke dan Iannaccone (1993) menguatkan teori Mara Einstein bahwa:

"...the market model views churches and their clergy as religious producers who choose the characteristics of their product and the means of marketing it. Consumers in turn choose what religion, if any, they will accept and how extensively they will participate in it. In a competitive environment, a particular religious firm will flourish only if it provides a product at least as attractive as its competitors."

Industri yang didasarkan pada doktrin keagamaan, tulis Finke dan Iannaccone, hanya mungkin diterima dan berkembang selama ia mampu menyedia produk yang atraktif dibanding kompetitornya. Demikian, agama yang dengan rigid menentukan batas-batas moral, etika, dan nilai-nilai universalitas yang baik, tidak berarti membatasi kreatifitas manusia untuk melahirkan produk-produk yang menguntungkan secara ekonomi. Namun kreatifitas tersebut mestilah bertanggungjawab, dan selalu berjalan di atas rel yang sudah ditetapkan oleh agama melalui batasbatas aktivitas ekonomi. Hal tersebut dianggap penting, agar industri berbasis agama seperti bank syariah dapat sejalan dengan rasionalitas manusia serta dapat sejalan dengan kebutuhan individu. Dengan demikian, agama sesungguhnya telah menjadi semangat sekaligus menjadi kerangka yang positif bagi industri keuangan seperti perbankan syariah. Dalam hubungannya dengan bank syariah di Bengkulu, bukanlah hal luar biasa jika nasabah bank syariah di Provinsi Bengkulu menaruh harapan agar Bank Syariah di provinsi ini terus berkembang tetapi mesti semangkin kuat didasarkan pada nilai-nilai syariah.

$$
\text { Penjelasan lain terhadap bagaimana }
$$
mekanisme agama memandu perilaku, termasuk pilihan nasabah, berasal dari teori yang 
diperkenalkan oleh Laurence R. Iannaccone (1998). Ia menyebut teori tersebut dengan 'ekonomi agama': sebuah teori yang menjelaskan bagaimana agama meningkatkan performa ekonomi pada kondisi tertentu, bahkan melalui teori tersebut mampu menjelaskan bagaimana model ekonomi dapat dimodifikasi untuk menjawab pertanyaan yang terkait dengan belief, norms, dan values. Tidak hanya itu tentunya, teori ini setidaknya juga mampu mengekplorasi bagaimana agama mempengaruhi attitud ekonomi dan aktivitas individual; kelompok dan masyarakat. Lantas bagaimana kemungkinan teoritis tersebut dihubungkan dengan fakta bahwa di Provinsi Bengkulu, agama terlihat memandu pilihan nasabah melalui dua bentuk: Pertama, intervensi institusi keagamaan, misalnya melalui fatwa DSN MUI terkait produk-produk bank syariah. Kedua, melalui kreatifitas individu; praktisi; dan industri keuangan syariah untuk melahirkan produk-produk yang sejalan dengan doktrin Islam. Sehingga dengan demikian produk itu dapat memenuhi kebutuhan serta dapat menyaingi kompetitor. Alhasil, pasar bank syariah semangkin diminati.

Laurence R. Iannaccone (1998) memahami bahwa bank syariah lengkap dengan produk yang ditawarkannya adalah bentuk nyata bagaimana agama menjadi sistem referensi bagi institusi ekonomi. Tidak berlebihan jika kemudian para psikolog, antropolog, dan sosiolog memahami agama sebagai satu kategori yang paling krusial dan berpengaruh terhadap perilaku manusia. Bahkan agama mampu membentengi manusia dari pengaruh buruk "kalkulasi rasional."Bahkan tidak hanya dalam dimensi ekonomi, agama telah menunjukkan didigjayaan pada bidang sosial, tulis
Iannaccone. Faktanya di Amerika Serikat, sejak tahun 1955, sukarelawan yang berafiliasi pada agama tertentu jauh lebih banyak memberikan kontribusi pada pelayanan sosial jika dibanding dengan jumlah relawan dari kelas sosial lainnya. Bahkan di berbagai kajian memperlihatkan bahwa agama telah mampu menjadi penyemangat manusia untuk meningkatkan pendapatan, dan kualitas pendidikan.

Max Weber jauh sebelum kajian-kajian tentang relasi agama dan mekanismenya dalam mempengaruhi perekonomian, telah memaparkan dengan detail bahwa reformasi pada tubuh Kristen Protestan telah menjadi fondasi utama bagi perkembangan kapitalisme. Diperkuat oleh Samuelsson dan Tawney bahwa reformasi pada Kristen Protestan diartikan sebagai faktor utama yang menyebabkan berkembangnya kapitalisme modern. Mengapa demikian? Reformasi tersebut mendorong para teolog untuk menjadikan ekonomi sebagai ukuran dari keshalehan beragama. Semangkin seseorang tersebut mengejar kepentingan diri secara tulus, maka secara bersamaan ia telah membangun kerajaan Tuhan. Teori tersebut senada dengan statemen partisipan bahwa ketulusan dalam melakukan aktivitas ekonomi, dan didorong oleh keinginan untuk membahagiakan keluarga. Ia, secara langsung dan mungkin tanpa disadari, telah membangun kerajaan Tuhan (Panca, 2015). Agaknya jika ditarik ke dalam konteks bank syariah dan pilihan terhadapnya, maka peran Islam dalam membentuk pilihan nasabah dapat dilacak dari beliefatau kepercayaan bahwa dengan memilih bank syariah berarti secara langsung, dan mungkin tanpa disadari telah menegakkan ajaran Islam dan memperkuat penerapan prinsip-prinsip 
syariah dalam sektor perbankan. Pertanyaan lain yang muncul adalah: "apakah pilihan nasabah terhadap bank syariah di Provinsi Bengkulu dapat diartikan sebagai praktek keagamaan sekaligus menjadi signifier dari keshalehan nasabah?”.

\section{KESIMPULAN}

Dari kajian yang dilakukan setidaknya dapat dikemukan setidaknya ada tiga tesis penting terkait dengan perilaku pilihan nasabah bank syariah di Provinsi Bengkulu, yakni: Pertama, pada tahap awal tatkala nasabah akan memilih bank syariah, ada kecenderungan pilihan tersebut dimotivasi oleh nalar-nalar instrumental seperti keinginan untuk mendapatkan profit lebih tinggi melalui skema bagi hasil yang ditawarkan oleh bank syariah. Kedua, pada tahap ini setelah nasabah memilih dan berinteraksi secara langsung dan intens dengan bank syariah, kesadaran akan nilai-nilai agama yang diekspresikan oleh bank syariah mulai tumbuh. Hal ini didorong oleh produk bank syariah sesungguhnya berbeda dengan bank konvensional—-terdiffrensiasi, tidak hanya pada aspek bentuk; dan akad tetapi juga pada dimensi prinsip yang mendasari produk tersebut. Ketiga, munculnya kesadaran bahwa bank syariah berbeda sehingga memunculkan mood-positive di kalangan nasabah bank syariah, dan akhirnya mereka menyadari bahwa mendasari pilihan atas pertimbangan nilai seperti agama jauh lebih utama akan menimbulkan keberkahan. Lebih detail, hasil temuan kajian ini dapat disederhanakan sebagai berikut:

Satu tesis yang dapat diajukan sebagai sesuatu yang empiris bahwa nasabah bank syariah di Provinsi Bengkulu, awalnya memang bertujuan berburu profit, tetapi menjadi religius kemudian. Menguatkan tesis tersebut, berangkat dari rumusan dan batasan masalah, agaknya secara empiris kajian ini menghasilkan beberapa temuan, yakni: Pertama, mekanisme agama memandu pilihan nasabah dapat dilihat dari fungsi dan posisi agama dalam membentuk atau paling tidak mewarnai pilihan nasabah bank syariah di Provinsi Bengkulu. Demikian, setidaknya ada 4 (empat) mekanisme yang diproduksi oleh agama dalam hal ini Islam membentuk pilihan nasabah, dan mekanisme tersebut adalah: legislasi, force of law, intervensi institusional dan modifikasi agama. Empat hal ini secara utuh ditemukan pada peran fatwa MUI (baca; fatwa haramnya bunga bank) sebagai attraktor yang membentuk pilihan nasabah bank syariah. Sederhananya kategori tersebut dapat dirasionalisasikan bahwa hadirnya Majelis Ulama Indonesia melalui fatwa haramnya bunga bank dapat ditafsirkan ke dalam beberapa kategori: Pertama, fatwa tersebut merupakan upaya melakukan legislasi atas haramnya bunga bank; Kedua, fatwa tersebut diartikan sebagai tekanan lewat hukum (force of law) agar umat Islam meninggalkan transaksi bank yang berbasis pada bunga; Ketiga, menguatnya peran MUI melalui fatwa Dewan Syariah Nasional agaknya dapat diartikan sebagai salah satu bentuk intervensi institusi agama mendukung, dan meningkatkan sphere-market bank syariah di Indonesia; dan Keempat, terlibatnya MUI dalam industri keuangan menjadi indikator tengah terjadinya modifikasi agama. Empat hal tersebut adalah mekanisme struktural dimana agama mewarnai pilihan nasabah melalui peran institusi agama. Tetapi secara kultural-psikologis, agama mempengaruhi pilihan nasabah melalui 
penghayatan terhadap doktrin dan pseuma (baca: spirit) religiusitas dalam hubungannya dengan bank syariah. Hingga akhirnya agama dijadikan sebagai nalar dibalik pilihan terhadap bank syariah.

Kedua, untuk menyimpulkan apakah pilihan nasabah terhadap bank syariah merupakan keshalehan agama dan praktek keagamaan tentu bukan hal yang "gamblang". Mengapa demikian? Pilihan nasabah terhadap bank syariah di Provinsi Bengkulu dibentuk oleh dua nalar secara simultan, yakni nalar instrumental dan nalar tradisional. Eksistensi dua nalar ini melahirkan dua model penghayatan yang berbeda, yakni: 1) sebagian nasabah, melalui pemaknaan atas personal-feeling partisipan, merupakan individu yang memahami bahwa pilihan terhadap bank syariah bukanlah produk dari agama atau praktek keagamaan. Tetapi ia adalah produk dari motivasi pribadi yang lebih kalkulatif; dan 2) sebagian partisipan mengungkapkan hal sebaliknya dimana pilihan mereka terhadap bank syariah di Provinsi Bengkulu adalah produk dari penghayatan terhadap spirit religiusitas, sehingga tujuan memilih bank didasari oleh keinginan untuk mendapatkan keberkahan.

Ketiga, rasionalisasi pilihan nasabah bank syariah dapat dilihat dari munculnya dua bentuk nalar, yakni nalar instrumental dan tradisional. Dua nalar ini akan menjadi cognitive system yang menjadi alasan mengapa pilihan terhadap bank syariah diputuskan. Sederhananya ada beberapa kesimpulan peting terkait hal itu. Pertama, setiap tindakan secara sadar atau tidak selalu didasarkan pada kebutuhan ekonomi. Kedua, setiap tindakan manusia selalu didasarkan pada semacam kesadaran atau consciousness yang dibentuk oleh orientasi, dan tujuan yang ada dalam pikiran manusia adakalnya kesadaran itu sebagai sebuah produk dari doktrin agama, ataupun budaya. Dua hal ini ditemukan secara simultan dan utuh pada rasionalisasi pilihan nasabah terhadap bank syariah di Provinsi Bengkulu.

Keempat, ada dua kesimpulan penting terkait nalar apa yang dominan membentuk pilihan nasabah—nalar instrumental atau nalar tradisional: 1) sebagai satu hal yang bersipat ekspektasi, baik nalar instrumental maupun nalar tradisional ada dua hal yang sama-sama kuat dan equal menjadi kriteria dari pilihan nasabah. Hal tersebut dapat dilihat dari angka yang dihasilkan dari kuantifikasi kuesioner, dimana angka nalar instrumental $83.7 \%$. Sementara angka untuk nalar tradisional adalah $87.14 \%$. Data yang ditampilkan ini dipermukaan terkesan ambigu, dan bersipat paradoks karena bersipat gradual dan jawaban partisipan bersipat ganda. Sehingga sulit dijelaskan secara teoritis. Namun jawaban tersebut dapat dimaklumi setelah mendalami ekspektasi tersebut melalui in-depth interview. Sesungguhnya jawaban partisipan sebagai seorang nasabah bank syariah yang ditorehkan melalui kuesioner merupakan refleksi dari pseuma atau spirit yang berada di dalam diri; jiwa; dan pikiran nasabah. Spirit tersebut juga bersipat gradual, dengan ambiguitas yang sangat kentara. Mengapa diteorisasikan seperti itu? Fakta menunjukkan secara empiris, bahwa nasabah bank syariah di Provinsi Bengkulu secara gradual dan simultan mengangap penting kriteria instrumental dan tradisional dalam memutuskan pilihan. 2) Data yang dihasilkan oleh kuesioner, sesungguhnya terkonfirmasi melalui in-depth interview dimana nasabah bank syariah di Provinsi Bengkulu 
mengungkapkan bahwa nalar instrumental dan nalar tradisional dipahami bukan dalam bentuk dialekti, tetapi keduanya diposisikan secara simultan dan kronologis. Faktanya, pilihan sebagai personal-feeling dibentuk oleh motivasi ekonomi-materialistik yang kemudian pada tahap berikutnya mendorong munculnya kesadaran religiusitas yang lebih tinggi karena terkondisikan oleh produk dan suasana yang ditawarkan oleh bank syariah kepada nasabah.

\section{DAFTAR PUSTAKA}

Abduh, Muhamad dan Sukmana, Raditya. (2015, Maret 23). Deposit Behaviour in Indonesia Islamic Banking: Do Crisis and Fatwa Matter?. Retrived from http://irep.iium. edu.my/24033/1/Abduh_and_Sukmana,_ FRPS_2011.pdf.

Awam, Hayat M. \& Shahzad Bukhari, Khuram. (2011). Costumer's Criteria for Selecting an Islamic Bank: Evidence from Pakistan. Journal of Islamic Marketing. Vol. 2, No.1.

Babbie, Earl. (2011). The Basic Social Research. USA: Wadsworth.

Beal, Timothy K. \& Deal, William E. (2004). Theory for Religious Studies. New York: Routldge.

Beckford, James A. (2003). Social Theory and Religion, New York: Cambridge University Press.

Casey, Conerly \& Edgerton, Robert B. (2007). A Companion to Psychological Anthropology. Malden: Blackwell Publishing.
Chibnik, Michael. (2011). Anthropology, Economics and Choice. Austin: University of Texas Press.

Einstein, Mara. (2008). Marketing Religion in a Commercial Age. London: Routledge.

Geertz, Clifford. (1973). The Interpretation of Culture. New York: Basic Books, Inc., Publishers.

Iannaccone, Laurence R. (1998). Introduction to the Economics of Religion. Journal of Economic Literature. Vol. 36.

K. Denzin, Norman \& S. Lincoln, Yvonna. (2000). Handbook of Qualitative Research. London: Sage Publication.

K. Denzin, Norman \& S. Lincoln, Yvonna. (2009). Handbook of Qualitative Research. (Dariyatno, Terjemahan) Yogyakarta: Pustaka Pelajar.

Lechner , Frank J. (2006). Rational Choice and Religious Economies. Dalam James A. Beckford \& N.J. Demerath (ed.), Handbook of The Sociology of Religion. New York: Sage.

M. Morse, Janice. (2009). Developing Grounded Theory: The Second Generation. California: Left Coast Press.

Olson, Carl. (2011). Religious Studies: The Key Concepts. London: Routledge.

Orlikowski, Wanda J. (1988). IS research Paradigm: Method versus Substance. Paper Presented at The Academy of Management Meeting, Anaheim CA.

Rivai, Harif Amali. Identifikasi Faktor Penentu Keputusan Konsumen dalam Memilih Jasa Perbankan: Bank Syariah vs. Bank 
Konvensional. Research Report: Centre for

Banking Research (CBR)-Andalas University.

Sukhmono, Brilyan Rahmat. (2011). Pengaruh Label Syariah pada Lembaga Perbankan terhadap Jumlah Nasabah BNI Syariah Cabang Jakarta Selatan. (Skripsi: Program Studi Muamalat, Fakultas Syariah dan HukumUniversitas Negeri Syarif Hidayatullah, 2011).

Tibi, Bassam. (2001). Islam between Culture and Politics. New York: Palgrave McMillan.

Wimberley, Dale W. (1984). Socioeconomic Deprivation and Religious Selience: A Cognitive Behavioral Approach. The Sociological Quarterly 25 Spring.
Zakaria Bahari, Dalfiza Mohd. Yusof, \& Adnan, Ahmad Azrin. (2014). The Relationship between the Bank Choice Determinant and The Acceptance of Musharakah Mutanaqisah Home Financing among Malaysia Muslims. International Journal of Science Commerce and Hummanities. Vol. 2, No.

\section{Sumber Lain}

Panca. (2015, Oktober 20). Pastor Kristen Protestan. Personal Interview.

Prof. Dr. Rokhimin, M.Ag. (2015, Oktober 21). Personal Interview.

Slamet. (2015, Oktober 12). Pendeta Buddha. Personal Interview. 
